\title{
Cerivastatin, a HMG-CoA Reductase Inhibitor, Reduces Plasminogen Activator Inhibitor-1 (PAI-1) Expression in Endothelial Cells by Down-Regulation of Cellular Signaling and the Inhibition of PAI-1 Promoter Activity
}

\author{
Maria Swiatkowska ${ }^{1}$, Zofia Pawlowska ${ }^{1}$, Janusz Szemraj², Józef Drzewoski³ \\ Cezary Watala ${ }^{4, *}$ and Czeslaw S. Cierniewski ${ }^{1,5}$ \\ ${ }^{1}$ Department of Molecular and Medical Biophysics, ${ }^{2}$ Department of Biochemistry, Medical University of Lodz, \\ Mazowiecka 6/8, 92-215 Lodz, Poland \\ ${ }^{3}$ Department of Clinical Pharmacology, Medical University of Lodz, Rewolucji 1905r. 37/39, 90-214 Lodz, Poland \\ ${ }^{4}$ Department of Haemostatic Disorders, Medical University of Lodz, ul. Narutowicza 96, 90-141 Lodz, Poland \\ ${ }^{5}$ Center for Microbiology and Virology, Polish Academy of Sciences, Lodowa 106, 93-232 Lodz, Poland
}

Received June 25, 2002 Accepted September 12, 2002

\begin{abstract}
Statins, which competitively inhibit 3-hydroxy-3-methylglutaryl-coenzyme A (HMG-CoA) reductase activity and reduce mevalonate synthesis, are believed to exert a plethora of pleiotropic effects. In this report, molecular mechanisms of the inhibitory effect on plasminogen activator inhibitor type 1 (PAI-1) expression produced by cerivastatin (CRV), the most active compound in this class, were studied using monocultures of human endothelial cell line (EA.hy 926). CRV similar to another statin, lovastatin (LOV), significantly inhibited PAI-1 expression and its release from endothelial cells, nonstimulated and stimulated with TNF- $\alpha$. The inhibitory effect of CRV could be detected at the level of PAI-1 promoter in EA.hy 926 cells transfected with plasmid p800 LUC containing PAI-1 promoter fragment (+71 to -800$)$, as well as at the level of PAI-1 mRNA. The PAI-1 promoter activity was markedly suppressed in the nonstimulated cells and almost completely inhibited in TNF- $\alpha$-stimulated cells. In addition, CRV at low doses $\left(\mathrm{IC}_{50}\right.$ of $4-$ $6 \mu \mathrm{M}$ ) significantly inhibited mitogen-activated protein kinases (MAPKs) phosphorylation. The majority of inhibitory effects occurred at significantly lower concentrations for CRV compared to LOV. The mechanism by which CRV inhibits PAI-1 expression appears to be directly associated with geranylgeranylation of some cell proteins, since the inhibitory effect on PAI-1 expression can be reversed by geranylgeranylpyrophosphate but not by farnesyl-pyrophosphate.
\end{abstract}

Keywords: Cerivastatin, Lovastatin, HMG-CoA reductase inhibitors, PAI-1 promoter activity, Human endothelial cell

Statins, the selective inhibitors of 3-hydroxy-3-methylglutaryl-coenzyme A (HMG-CoA) reductase, a key enzyme in the synthesis of cholesterol, are the most effective agents currently available for lowering plasma levels of lowdensity lipoprotein cholesterol (LDL-C) and are the mainstay of therapy for hyperlipidemia $(1-3)$. Several large, controlled clinical trials have confirmed significant reductions in the rates of coronary heart disease morbidity and death with long-term statin therapy in patients with mild to severe hypercholesterolemia (4-6). Moreover, selected

*Corresponding author. FAX: +48 426791299

E-mail: cwatala@csk.am.lodz.pl,cwatala@toya.net.pl statins have been claimed to offer some potential benefits in addition to the lipid-lowering activity found in other statins $(7-10)$. The drugs were found to affect cellular mechanisms by influencing chemokines, expression of surface adhesion molecules, endothelin and nitric oxide synthase $(11-16)$. Furthermore, statins were described to inhibit activation of transcription nuclear factors NF- $\kappa \mathrm{B}$ and $\mathrm{AP}-1(17,18)$. Hence, the overall clinical benefit of HMG-CoA reductase inhibitors may derive from qualitative, functional changes in atherosclerotic lesions, as well as the amelioration of fibrinolytic parameters in addition to their lipid-lowering properties. By inhibiting the expression of plasminogen activator inhibitor type 1 (PAI-1) in endo- 
thelial cells, statins may alter the local fibrinolytic balance within the vessel wall toward increased fibrinolytic capacity that, in turn, would reduce thrombotic risk after plaque rupture $(19,20)$. The suggestion has been raised that HMGCoA reductase inhibitors may interfere with cellular signal transduction by blocking Rho GTPase geranylgeranylation and thus they may modulate the nuclear expression of some proteins, for example PAI-1 in endothelial cells (20).

To test this hypothesis, we studied molecular mechanisms by which some statins could reduce PAI-1 expression in endothelial cells, at the level of PAI-1 promoter and thus influence fibrinolytic balance in the vicinity of vessel wall. In the present study, we compared the action of two statins: lovastatin (LOV) and cerivastatin (CRV). While the former is the so called first-generation statin effective at relatively high therapeutic doses, the latter was once recognized as the most potent drug in this class with respect to its biopharmaceutical profile and bioavailability. Although no longer used in clinical practice due to some undesirable interference with other medications, CRV remains an excellent, very active HMG-CoA reductase inhibitor that may be employed in model studies. In this study, we have shown that the molecular mechanism(s) of the influence of CRV on fibrinolysis results from the inhibition of geranylgeranylation of some signalling proteins and involves the suppression of all the stages of signalling leading to PAI-1 gene expression in both basal and TNF- $\alpha$-stimulated endothelial cells.

\section{MATERIALS AND METHODS}

\section{Chemicals and materials}

Unless otherwise stated, all chemicals used were from Sigma Chemicals Co. (St. Louis, MO, USA). The ElisaImulyse PAI-1 immunoenzymatic kit was from Biopool (Umea, Sweden); and the rabbit polyclonal antibodies against active extracellular signal-regulated kinase (ERK1 /2), anti-(rabbit IgG) Ig horseradish peroxidase conjugates, TNF- $\alpha$, reporter vector pGL3, as well as the Luciferase Assay System, were from Promega (Madison, WI, USA). All standard tissue culture reagents including DMEM, fetal calf serum (FCS), $\beta$-galactosidase Enzyme Assay System and LipofectAMINE Plus reagent were from Gibco Life Technologies Ltd. (Paisley, UK). Protein assay reagents and polyacrylamide gel chemicals were from BioRad (Richmond, CA, USA). Cerivastatin sodium (CRV) was a kind gift from Bayer AG (Zurich, Switzerland), and the plasmid p800LUC with PAI-1 promoter was obtained as a gift from Dr. David J. Loskutoff from Department of Immunology, Scripps Clinic and Research Foundation (La Jolla, CA, USA).

\section{Cell cultures}

The human endothelial cell line EA.hy 926, derived by fusion of human umbilical vein endothelial cells with continuous human lung carcinoma cell line A549, was obtained as a gift from Professor Cora-Jean S. Edgell (Pathology Department, University of North Carolina at Chapel Hill, NC, USA). EA.hy 926 cells closely resemble human umbilical vein endothelial cells and maintain the characteristics of differentiated endothelium $(21,22)$. The cells were cultured in growth medium containing DMEM, HAT (100 $\mu \mathrm{M}$ hypoxanthine, $0.4 \mu \mathrm{M}$ aminopterin, $16 \mu \mathrm{M}$ thimidine) and $10 \%$ FCS in a $90-95 \%$ humidified atmosphere of $5 \% \mathrm{CO}_{2}$ at $37^{\circ} \mathrm{C}$. To evaluate the effect of either statin on PAI-1 expression at the level of protein synthesis, EA.hy 926 cells were grown on 48 -well microplates. The cells were continuously kept at their logarithmic growth phase by diluting and supplying them with fresh culture medium every two or three days. All cultures were free of mycoplasma. Prior to the treatment with either LOV or $\mathrm{CRV}$, the cell medium was changed and the cells starved for $12 \mathrm{~h}$ in DMEM supplemented with $0.1 \%$ FCS to ensure the appropriate cell synchronisation. Such conditions neither affected cell viability nor caused any detectable increase cell activation (not shown) (23). Then LOV (10$80 \mu \mathrm{M})$ or $\mathrm{CRV}(0.01-20 \mu \mathrm{M})$ were added and the cells were further incubated for $24 \mathrm{~h}$ in 48 -well microplates. Optionally, to determine whether the effects of CRV on PAI-1 synthesis might be mediated by protein isoprenylation, the incubation of cultured endothelial cells with $1 \mu \mathrm{M}$ CRV was performed in the presence of either $15 \mu \mathrm{M}$ farnesyl pyrophosphate (FPP) or $15 \mu \mathrm{M}$ geranylgeranyl pyrophosphate (GGPP) (20). At the termination of cell growth, the media were collected, and PAI-1 antigen was determined immunoenzymatically. For kinase assays, cells cultured in $10-\mathrm{cm}$ Petri dishes were preincubated with $0-$ $20 \mu \mathrm{M} \mathrm{CRV}$ for $30 \mathrm{~min}$ prior to the activation with $50 \mathrm{ng}$ $/ \mathrm{ml} \mathrm{TNF}-\alpha$ (20 min). Then they were washed twice with cold PBS and lysed in $300 \mu \mathrm{l}$ of the lysis buffer $(20 \mathrm{mM}$ Hepes, pH 7.5, $150 \mathrm{mM} \mathrm{NaCl}, 10 \%$ glycerol, 1\% Triton $\mathrm{X}-100,1.5 \mathrm{mM} \mathrm{MgCl}_{2}, 1 \mathrm{mM}$ PMSF, $2 \mathrm{mM}$ sodium orthovanadate, $50 \mathrm{mM} \mathrm{NaF}, 10 \mathrm{mM}$ sodium pyrophosphate, $1 \mu \mathrm{g} / \mathrm{ml}$ leupetin, $1 \mu \mathrm{g} / \mathrm{ml}$ aprotinin). Cell lysates were harvested by centrifugation at $14,000 \times g$ for $5 \mathrm{~min}$, $4^{\circ} \mathrm{C}$.

To monitor cytotoxic effects, endothelial cells kept for $24 \mathrm{~h}$ at $37^{\circ} \mathrm{C}$ in medium supplemented with FCS were treated with $0-20 \mu \mathrm{M} \mathrm{CRV}$ or $0-80 \mu \mathrm{M}$ LOV. Then, the endothelial cell viability was determined microscopically by Trypan Blue exclusion. In addition, apoptotic effects of statins within the concentrations used were evaluated by flow cytometry using an Annexin V-FITC Apoptosis Detection Kit (Sigma). Only cell cultures showing less than $1 \%$ dead cells were included into the study. 


\section{Kinase assays}

Kinase assays were performed as described before (23). The treatment of cells with TNF- $\alpha(50 \mathrm{ng} / \mathrm{ml})$ for $20 \mathrm{~min}$ was used to reach a maximum activation of ERK $1 / 2$. Aliquots of cell lysates containing $20 \mu \mathrm{g}$ protein were separated by SDS/PAGE and electrophoretically transferred to nitrocellulose membranes $(0.45-\mu \mathrm{m}$ pore size $)$. Mitogen-activated protein kinases (MAPKs) were detected with polyclonal antibody specific to the active forms of ERK1/2 (dilution 1:1000, Promega). The concentration of the phosphorylated form of MAPK was evaluated by Western immunoblotting. Immunodetection was accomplished using the enhanced chemiluminescence kit (ECL Kit; Amersham, Little Chalfont, UK), and then films were scanned and protein bands quantitated with the use of Gel Doc $^{\mathrm{TM}} 2000$ Gel Documentation System (Bio-Rad).

\section{Transfection of cells}

Semiconfluent cell cultures (EA.hy 926) in 6-well tissue culture plates were transfected with DNA constructs (plasmid p800LUC with PAI-1 promoter) using the lipofectAMINE method. Cells were transfected with $4 \mu \mathrm{g}$ of p800 LUC containing PAI-1 promoter and $5 \mu \mathrm{g}$ of pSV vector containing the $\beta$-galactosidase gene to evaluate the transfection efficiency. For statin studies, either CRV (2 $20 \mu \mathrm{M})$ or $\operatorname{LOV}(20-80 \mu \mathrm{M})$ were added to the wells of culture plates, cells were incubated for $24 \mathrm{~h}$, and then the cells were washed and harvested in the lysis buffer. After centrifugation for $5 \mathrm{~min}$ at $4^{\circ} \mathrm{C}$, the supernatants were transferred into fresh vials and used for enzymatic assays. A luciferase assay kit was used according to the manufacturer's instructions, using a liquid scintillation counter (Beckman LS6000LL; Beckman Instruments, Fullerton, CA, USA). $\beta$-Galactosidase activity from a constitutively expressed internal control was assayed with a $\beta$-galactosidase Enzyme Assay System according to manufacturer's instructions and with the use of a microplate reader (EL340; Bio-Tek Instruments, Inc., Winooski, VT, USA). In parallel experiments, EA.hy 926 were transfected with the luciferase reporter vector pGL3 and used as a control cells to test whether the effects of statins were specific for PAI-1 promoter.

\section{PAI-1 antigen and $m R N A$ analysis}

PAI-1 antigen was assayed as described before (23). Total cellular RNAs were extracted from human endothelial cells using the Trizol reagent method, a single-step purification protocol (24). The concentration and purity of total RNA were determinated by spectrophotometric readings at 260 and $280 \mathrm{~nm}$. The quality of the isolated total RNA was also checked by $1 \%$ agarose- $2 \mathrm{M}$ formaldehyde gel electrophoresis. A $1-\mu \mathrm{g}$ sample of total RNA was then used for cDNA synthesis by the SuperScript II RNase H
Reverse Transcriptase System, using oligo (dT) 12-18 primers. cDNA was amplified with forward and reverse primers specific for PAI-1 (5'GCTGAATTCCTGGAG CTCAG3', 5'CTGCGCCACCTGCTGAAACA3') or $\beta$ actin (5'GTGGGGCGCCCCAGGCACCA3' 5'CTCCTTA ATGTCACGCACGATTTC3') cDNA. The amplification products $\left(35\right.$ cycles each including $95^{\circ} \mathrm{C}, 30 \mathrm{~s} ; 59^{\circ} \mathrm{C}, 30 \mathrm{~s}$; $72^{\circ} \mathrm{C}, 30 \mathrm{~s}$ ) were resolved on the $6 \%$ polyacrylamide gel.

\section{Statistical analyses}

All data are presented as the means of the averaged replicates \pm S.E.M. The normal distribution of data was confirmed using Shapiro-Wilk's W test. The randomized block design of the analysis of variance (25) were employed to assess the significance of differences among groups. Significant difference was taken for $P$ values less than 0.05 .

\section{RESULTS}

Inhibition of PAI-1 expression in endothelial cells by cerivastatin and lovastatin

To examine the in vitro effects of statins on PAI-1 expression, EA.hy 926 cells were cultured in the presence of increasing concentrations of CRV or LOV for $24 \mathrm{~h}$ and the modulation of PAI-1 synthesis was evaluated based on amounts of the PAI-1 antigen released into the medium. Basal expression of PAI-1 yielded a release of $21.0 \pm 3.4 \mathrm{ng}$ by $1 \times 10^{5}$ cells, while stimulation of EA.hy 926 with TNF$\alpha$ resulted in the increased release of PAI- 1 to the medium that reached $54.7 \pm 5.4 \mathrm{ng}$. Figure 1 shows that both CRV and LOV inhibited the release of PAI-1 from endothelial cells in monocultures in a concentration-dependent manner. The significant inhibition of PAI-1 release from EA.hy 926 by CRV and LOV was already marked at low concentrations of $0.1 \mu \mathrm{M}(P<0.001)$ and $20 \mu \mathrm{M}(P<0.001)$, respectively. Interestingly, the extent of inhibition in the case of CRV was the same, when basal PAI-1 expression and TNF- $\alpha$ stimulated expression were studied. The inhibitory efficiency was significantly higher in the case of CRV when compared to that produced by LOV, particularly for the TNF- $\alpha$-stimulated cells $(P<0.001)$ (Fig. 1: A and B). To study the responsiveness of endothelial cells to statins at the PAI-1 promoter level, subconfluent EA.hy 926 cells were transfected with plasmid p800LUC containing PAI-1 promoter fragment corresponding to positions from +71 to -800. Preliminary comparative functional studies, with the firefly luciferase gene as a reporter, showed that this construct exhibited high promoter activity in the transfected cells that could be inhibited by LOV and CRV in a dose dependent manner (Fig. 2). Both statins, strongly inhibited PAI-1 promoter activity in the nonstimulated EA.hy 926 cells (Fig. 2A), and CRV was again a much stronger inhi- 
A

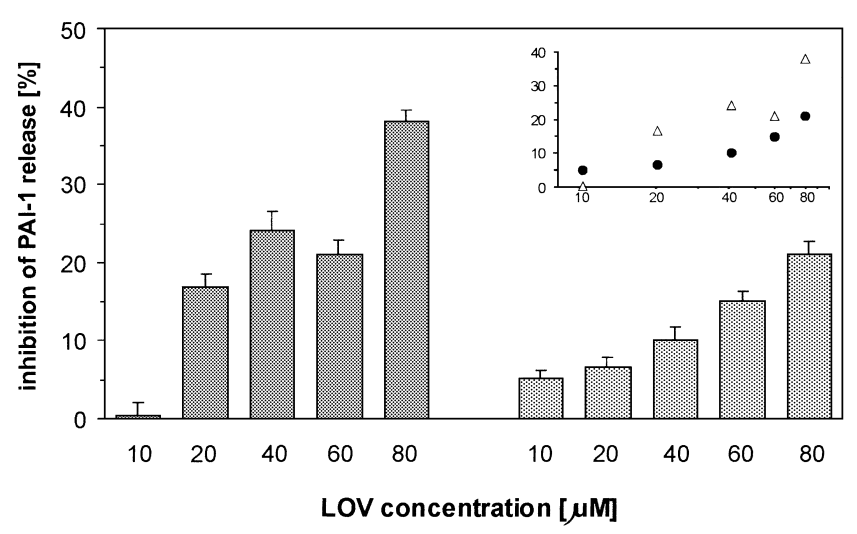

B

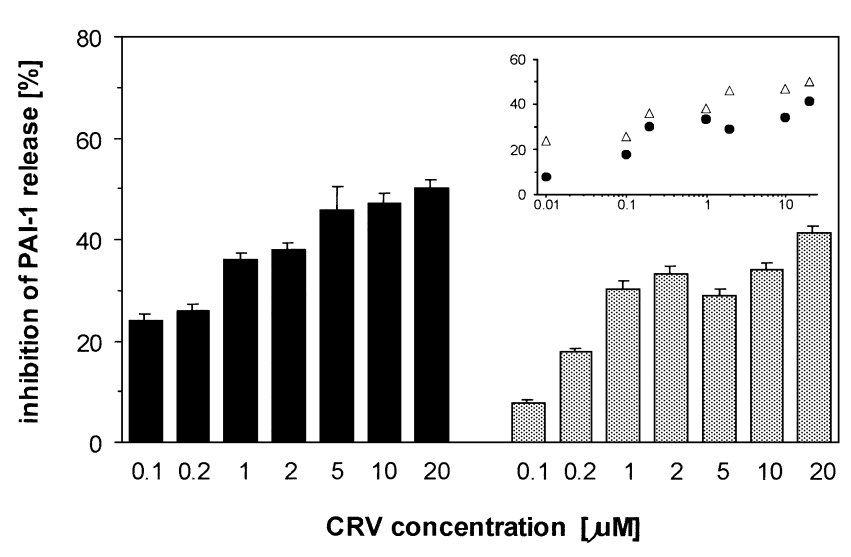

Fig. 1. Inhibition of PAI-1 release from EA.hy 926 cells by lovastatin and cerivastatin. The effect of both lovastatin (Panel A) and cerivastatin (Panel B) was tested on basal expression of PAI-1 (black bars, open triangles) and upon stimulation with TNF- $\alpha$ (grey bars, solid circles). Prior to the treatment with statins, cells were starved in DMEM supplemented with $0.1 \%$ FCS for $12 \mathrm{~h}$. Cells were incubated for $24 \mathrm{~h}$ either with lovastatin $(10-80 \mu \mathrm{M})$ or cerivastatin $(0.01-20 \mu \mathrm{M})$, then media were collected, and PAI-1 antigen determined by ELISA. Results are expressed as the inhibition of PAI-1 release ( $\%$ of control) and represent means \pm S.E.M. of six independent experiments. Significances of differences between concentrations, estimated by the Tukey multiple comparison test, and significances of linear regression slope were: LOV, for nonactivated cells (basal): $\mu_{\text {con }}=\mu_{10} \neq \mu_{20}=\mu_{40}=\mu_{60} \neq \mu_{80}, P<0.0001$; $P_{\text {slope }}<0.0001$; LOV, for TNF- $\alpha$-activated cells: $\mu_{\text {con }}=\mu_{10}=\mu_{20}=$ $\mu_{40}=\mu_{60} \neq \mu_{80}, P<0.04 ; P_{\text {slope }}<0.0001$; CRV, for non-activated cells (basal): $\mu_{\text {con }} \neq \mu_{0.1}=\mu_{0.2} \neq \mu_{1}=\mu_{2}=\mu_{10}=\mu_{20}, P<0.001 ; P_{\text {slope }}<0.0001$; CRV, for TNF- $\alpha$-activated cells: $\mu_{\text {con }} \neq \mu_{0.1} \neq \mu_{0.2} \neq \mu_{1}=\mu_{2}=\mu_{10} \neq$ $\mu_{20}, P<0.005 ; P_{\text {slope }}<0.0001$.

bitor then LOV. When used at $20 \mu \mathrm{M}$, it produced a $65 \pm 8 \%$ reduction in luciferase activity, as compared to control nontreated cells. This effect was even stronger when EA.hy 926 cells were stimulated with TNF- $\alpha$ (Fig. 2B). Under such conditions, CRV used at concentration of $20 \mu \mathrm{M}$ produced approximately eightfold inhibition of PAI-1 promoter activity. This very strong inhibitory
A

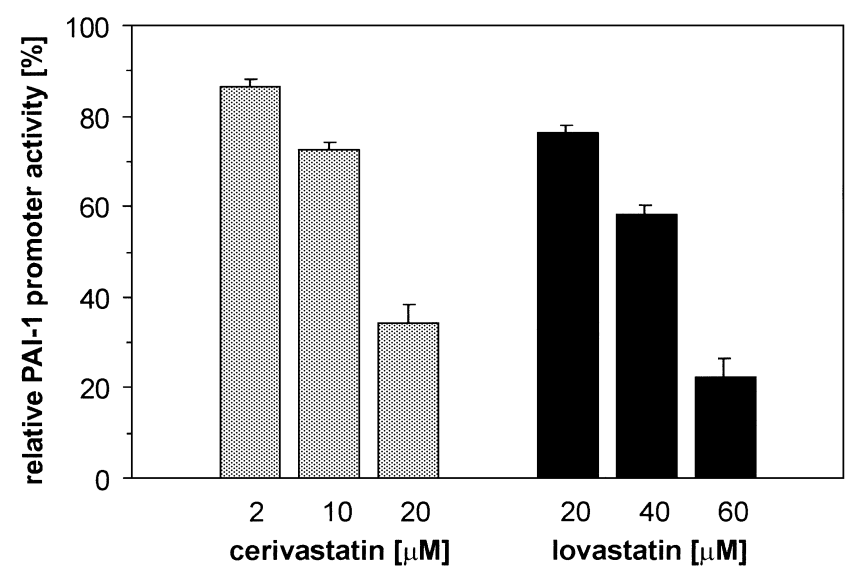

B

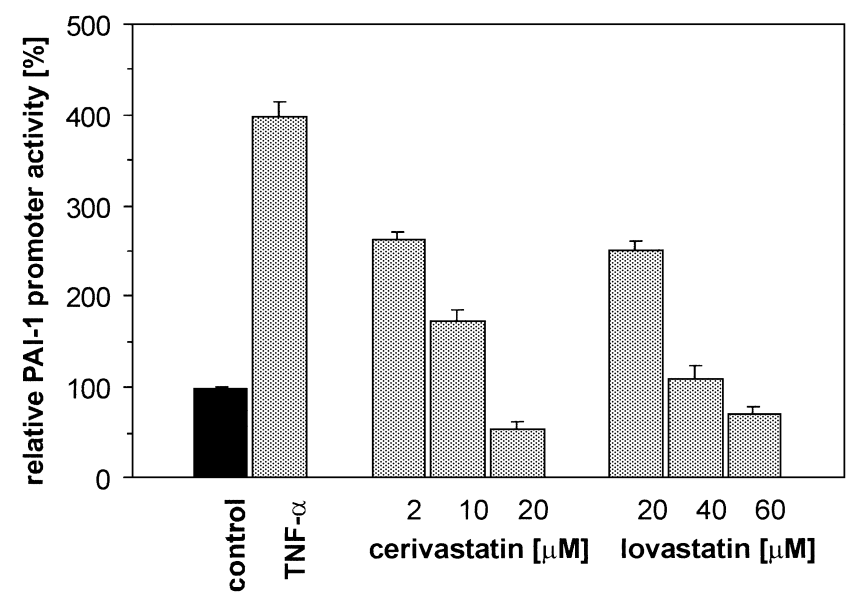

Fig. 2. Regulation of the activity of PAI-1 promoter construct in EA.hy 926 cells by lovastatin and cerivastatin. Semiconfluent cell cultures were transfected with DNA constructs (plasmid p800LUC with PAI-1 promoter) using the lipofectAMINE method. Cells were incubated for $24 \mathrm{~h}$ either with cerivastatin $(2 \mu \mathrm{M}, 10 \mu \mathrm{M}$ and $20 \mu \mathrm{M})$ or lovastatin $(20,40$ and $60 \mu \mathrm{M})$, washed, harvested in the lysis buffer, and centrifuged. Luciferase assays were performed in the tenfold diluted cell supernatants. The effect of statins on the PAI-1 promoter activity was tested in the nonstimulated cells (panel A) and after stimulation with TNF- $\alpha$ (panel B). Data are expressed as the relative changes in control values (basal expression assumed to be equal $100 \%$ ). Values represent means \pm S.E.M. of six independent experiments. Significances of differences, estimated by the Tukey multiple comparison test, were $P<0.05$ or less for all the inter-group comparisons.

effect of CRV on TNF- $\alpha$-induced expression of PAI- 1 was also well documented by rt-PCR analysis of actin and PAI-1 mRNA (Fig. 3). Treatment of cells with TNF- $\alpha$ significantly increased the expression of PAI-1 mRNA but did not affect the actin mRNA level. CRV reduced the PAI-1 mRNA in a dose-dependent manner: 1.0 $\mu \mathrm{M} \mathrm{CRV}$ resulted in approximately $50 \%$ inhibition of PAI- 1 mRNA 


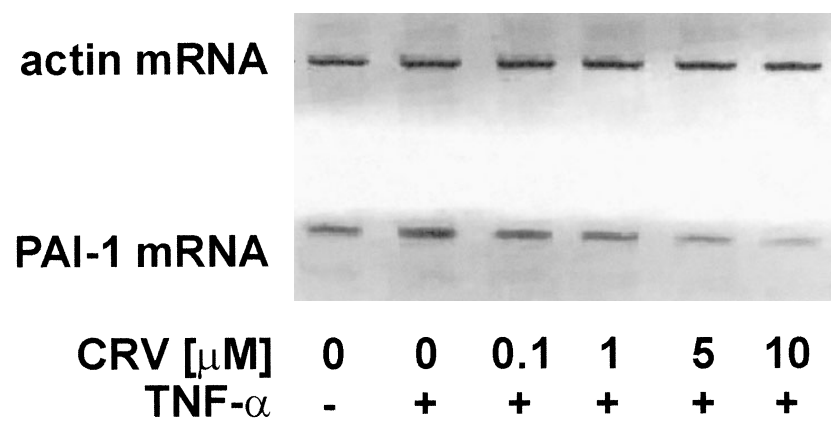

Fig. 3. Effect of cerivastatin on PAI-1 mRNA synthesis in EA.hy 926 cells. The cells were preincubated with the increased concentrations of cerivastatin and treated with $50 \mathrm{ng} / \mathrm{ml}$ TNF- $\alpha$. Cells not treated with cerivastatin and TNF- $\alpha$ were referred to as basal expression (control).

synthesis and this deepened with increasing CRV concentration.

Role of MAPK in down-regulation of PAI-1 expression by cerivastatin

To determine the possible molecular mechanism(s) of the reduction of PAI-1 expression by the increasing concentrations of CRV, we also evaluated the extents of protein phosphorylation on serine/threonine and tyrosine residues. In our previous studies, we have shown that protein phosphorylation of ERK $1 / 2$ is involved in the signalling cascade leading to activation of PAI-1 expression (23). Therefore, we selected MAPK to check whether its phosphorylation is influenced by CRV under the conditions that we used to analyze PAI-1 expression in EA.hy 926 cells. Fig. 4 shows a down-regulation of ERK1/2, as well as the estimates of CRV-induced inhibition in resting and TNF$\alpha$-stimulated EA.hy 926 cells by the increasing statin concentrations. The inhibitory effect of CRV on ERK1/2 was associated with drug concentration and there was almost complete blocking of phosphorylation of ERK $1 / 2$ at the highest concentration of the inhibitor used. The inhibitory effect of CRV on ERK1/2 was associated with drug concentration: even at low doses, the phosphorylation of ERK1/2 was significantly inhibited, and this deepened with the increasing statin concentration $\left(\mathrm{IC}_{50}\right.$ of $\left.4-6 \mu \mathrm{M}\right)$.

\section{Effect of isoprenoids on PAI-1 expression}

To test whether the inhibitory effects of CRV on PAI-1 expression can be reversed by isoprenylation of cell proteins, we performed a series of experiments to analyze the effect of the early metabolites formed along the mevalonate pathway of cholesterol synthesis on the PAI-1 expression in endothelial cells. Two of these intermediates, FPP and GGPP, are involved in a posttranslational regulation of protein function by means of their modification resulting from the attachment of the isoprenoid residuals to the pro-
A

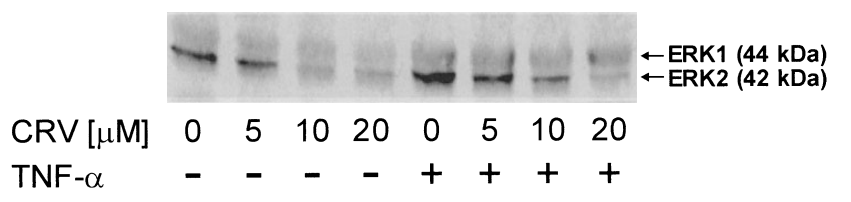

B

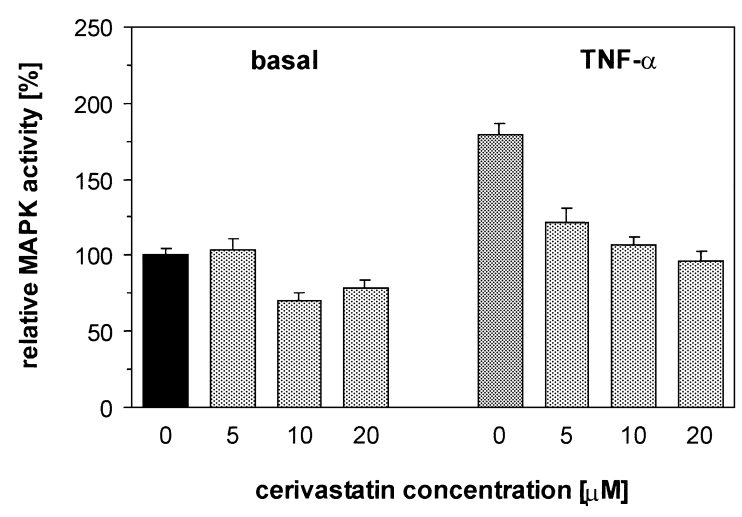

Fig. 4. Down-regulation of ERK $1 / 2$ signalling by cerivastatin. EA.hy 926 cells were preincubated with different concentrations of cerivastatin for $30 \mathrm{~min}$ prior to $20 \mathrm{~min}$ activation with $50 \mathrm{ng} / \mathrm{ml}$ TNF- $\alpha$, then cells were washed twice with cold PBS, lysed, and MAPKs were detected with polyclonal antibodies specific to active forms of ERK1/2 (panel A). Estimates in panel B are for ERK2 subunit with a stronger response to CRV. Data are expressed as the relative changes in control values (basal expression assumed to be equal $100 \%$ ). Values are means \pm S.E.M. of six independent experiments. Significances of differences, estimated by the Tukey multiple comparison test, were: for non-activated cells (basal): $\mu_{\mathrm{CRV} 5} \neq \mu_{\mathrm{CRV} 20}$, $P<0.05$; for TNF- $\alpha$-activated cells: $\mu_{\text {con }} \neq \mu_{\mathrm{CRV} 5} \neq \mu_{\mathrm{CRV} 20}, P<0.03$ or less.

tein $\mathrm{COOH}$ terminal part. To determine whether the effects of CRV might be mediated by such a protein isoprenylation, the inhibitory effect of CRV $(1 \mu \mathrm{M})$ on PAI-1 expression in endothelial cells was monitored in the absence or presence of either FPP $(15 \mu \mathrm{M})$ or GGPP $(15 \mu \mathrm{M})$. When acting alone, neither FPP nor GGPP noticeably modify PAI-1 expression (not shown). In the presence of CRV, GGPP reversed the statin-mediated reduction of PAI-1 expression, suggesting that geranylgeranylation is involved in the regulation of PAI-1 expression. Otherwise, FPP did not affect the inhibition of PAI-1 synthesis and release, indicating that modulation of farnesylated proteins is not associated with the regulation of PAI-1 expression in endothelial cells. These effects were particularly marked for basal PAI-1 expression in endothelial cells not stimulated with TNF- $\alpha$. Although the tendencies that occurred upon the stimulation with TNF- $\alpha$ were very much alike, the differences remained below statistical significance (Fig. 5). 


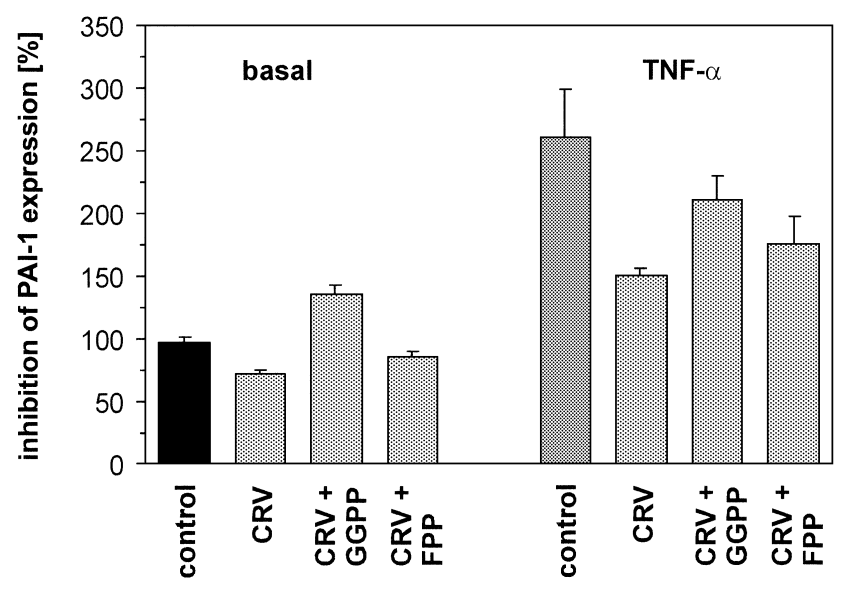

Fig. 5. Isoprenylation of cell proteins and PAI-1 expression. EA.hy 926 cells were incubated with $1 \mu \mathrm{M}$ cerivastatin in the presence or absence of either farnesyl pyrophosphate (FPP, $15 \mu \mathrm{M}$ ) or geranylgeranyl pyrophosphate (GGPP, $15 \mu \mathrm{M}$ ). PAI-1 antigen released to the experimental medium was determined by ELISA. Data are expressed as the relative changes in control values (basal expression assumed to be equal $100 \%$ ). Values are the mean \pm S.E.M. of three independent experiments. Significances of differences, estimated by the Tukey multiple comparison test, were: for nonactivated cells (basal): $\mu_{\mathrm{con}} \neq \mu_{\mathrm{CRV}}, \mu_{\mathrm{CRV}+\mathrm{GGPP}}, P<0.04$ or less; $\mu_{\mathrm{CRV}} \neq$ $\mu_{\mathrm{CRV}+\mathrm{GGPP}}, P<0.0001 ; \mu_{\mathrm{CRV}+\mathrm{PPP}} \neq \mu_{\mathrm{CRV}+\mathrm{GGPP}}, \quad P<0.001$; for TNF- $\alpha$ activated cells: $\mu_{\mathrm{con}} \neq \mu_{\mathrm{CRV}}, P<0.05$.

\section{DISCUSSION}

Inhibitors of HMG-CoA reductase have been recently shown to prevent atherosclerosis progression $(26,27)$ and cardiovascular disease $(28,29)$. Clinical benefits of the inhibitor administration are believed to result from multiple effects on the components of the atherosclerotic lesions, including their marked influence on the endothelial fibrinolytic system (20). LOV and very occasionally also other statins have been reported to modulate the balance between t-PA and PAI-1 by inducing t-PA synthesis and/or decreasing PAI-1 synthesis in endothelial cells $(20,30,31)$. In the present study, we confirmed that LOV appears as a profibrinolytic agent in endothelial cells, and so does CRV, however, with much enhanced efficacy. Furthermore, we demonstrated that the mechanism(s) by which statins inhibit PAI-1 synthesis in endothelial cells is rather complex and can be monitored also at the level of PAI-1 promoter. It is believed that the antiatherosclerotic effects of statins may be achieved not only by modifying hypercholesterolemia $(2,3)$ but also the whole arterial wall environment (29, $32-34)$. Once used in clinical practice, CRV was distinguished by its high pharmacological potency and the concurring high liver selectivity, which enabled the administration of the drug at $1-5 \%$ of the dose of other currently available HMG-CoA reductase inhibitors (35). The beneficial effects of CRV on fibrinolytic balance, albeit easily predicted per analogiam to other clinically used statins, have only very sporadically been reported (31).

In this study, we show that effects of statins on fibrinolytic balance may be a more universal phenomenon, since we provide unambiguous evidence that $\mathrm{CRV}$ was a highly efficient modulator of PAI-1 synthesis and release from monocultured Ea.hy 926 endothelial cells. On the other hand, however, our findings on the model endothelial cell line should be interpreted with caution and cannot be directly extrapolated to all endothelial cells. In our study, we showed that CRV was much more potent and suppressive for PAI-1 synthesis and release compared to statins of the older generation, like LOV. The suppressive effects of CRV on PAI-1 expression occurred already at doses relevant to those achieved in a course of pharmacological treatment in clinical practice. In both nonstimulated and TNF- $\alpha$ stimulated endothelial cells, CRV appeared up to 80 -fold more potent in the inhibition of PAI- 1 release than LOV. Furthermore, we evidenced that such an inhibition of PAI-1 synthesis and release was through the modulation of PAI-1 promoter activity, since mRNA expression in endothelial cells transfected with PAI-1 promoter construct was markedly suppressed in the presence of CRV and, to much lower extent, also in the presence of LOV. In addition to that, CRV also markedly inhibited protein phosphorylation on tyrosine, serine and threonine residues, which supports our further reasoning on the crucial role of the MAPK cascade in the CRV-induced suppression of PAI-1 synthesis and/or release in endothelial cells.

Previous occasional studies clearly showed that HMGCoA reductase inhibitors were able to modulate the plasminogen-plasmin pathway and pointed to the principal role of the process of geranylgeranylation of Rho protein(s) in modulating of PAI-1 activity (20). It has been shown for instance that the effect of LOV was associated with a disruption of intracellular actin fibers, the effect reversed by GGPP, and reproduced by C3 exoenzyme (an inhibitor of the geranylgeranylated-activated Rho protein), and that such a disruption modified fibrinolytic potential most likely via an inhibition of geranylgeranylated Rho protein and a disruption of the cytoskeleton. The role of Rho protein, a possible target for statins, acquires even more importance in the light of the finding that Rho GTPase negatively regulated endothelial nitric oxide synthase mRNA stability $(10,36)$. Hence, as far as HMG-CoA reductase inhibitors have been shown to block Rho geranylgeranylation, which is necessary for its membrane-associated activity, it seems reasonably certain that these drugs may be also able to up-regulate eNOS expression, and thus have an impact on a fibrinolytic balance $(37-41)$.

Although we did not directly evidence that CRV promotes disruption of cytoskeleton components crucial for MAPK signalling, our results may favor the hypothesis 
that CRV attenuates signal transduction, finally leading to the alterations in gene transcription. One might speculate on the putative molecular mechanism(s) of CRV action. It seems possible that CRV, per analogiam to other statins, might impair triggering of cellular signal transduction, possibly due to modulation of lipid-protein interactions, and the resultant impairments in the anchoring of some crucial signal proteins in a lipid bilayer of cellular membrane.

\section{Acknowledgments}

This work was partly supported by Projects 6P04A 00215 and 6P04A 06620 from the Polish Committee for Scientific Research.

\section{REFERENCES}

1 Farnier $\mathrm{M}$ and Davignon $\mathrm{J}$ : Current and future treatment of hyperlipidemia: the role of statins. Am J Cardiol 82, 3J-10J (1998)

2 Blumenthal RS: Statins: effective antiatherosclerotic therapy. Am Heart J 139, 577 - 583 (2000)

3 Perreault S, Levinton C and Le Lorier J: Efficacy and cost of HMG-CoA reductase inhibitors in the treatment of patients with primary hyperlipidemia. Can J Clin Pharmacol 7, $144-$ $154(2000)$

4 Scandinavian Simvastatin Survival Study Group: Randomised trial of cholesterol lowering in 4444 patients with coronary heart disease: the Scandinavian Simvastatin Survival Study (4S). Lancet 344, 1383 - 1389 (1994)

5 Shepherd J, Cobbe SM, Ford I, Isles CG, Lorimer AR, MacFarlane PW, McKillop JH and Packard CJ: Prevention of coronary heart disease with pravastatin in men with hypercholesterolemia. West of Scotland Coronary Prevention Study Group. N Engl J Med 333, 1301 - 1307 (1995)

6 Treasure CB, Klein JL, Weintraub WS, Talley JD, Stillabower ME, Kosinski AS, Zhang J, Boccuzzi SJ, Cedarholm JC and Alexander RW: Beneficial effects of cholesterol-lowering therapy on the coronary endothelium in patients with coronary artery disease. N Engl J Med 332, 481 - 487 (1995)

7 Rubinstein A, Maritz FJ, Soule SG, Markel A, Chajek-Shaul T, Maislos M, Tal S and Stolero D: Efficacy and safety of cerivastatin for type 2 diabetes and hypercholesterolaemia. Hyperlipidaemia in Diabetes Mellitus investigators. J Cardiovasc Risk 6, 399 - 403 (1999)

8 Boberg M, Angerbauer R, Fey P, Kanhai WK, Karl W, Kern A, Ploschke J and Radtke M: Metabolism of cerivastatin by human liver microsomes in vitro. Characterization of primary metabolic pathways and of cytochrome P450 isozymes involved. Drug Metab Dispos 25, 321 - 331 (1997)

9 McClellan KJ, Wiseman LR and McTavish D: Cerivastatin. Drugs 55, 415 - 420 (1998)

10 Stein E, Sprecher D, Allenby KS, Tosiello RL, Whalen E and Ripa SR: Cerivastatin, a new potent synthetic HMG Co-A reductase inhibitor: effect of $0.2 \mathrm{mg}$ daily in subjects with primary hypercholesterolemia. J Cardiovasc Pharmacol Ther 2, 7 - 16 (1997)

11 Bellosta S, Bernini F, Ferri N, Quarato P, Canavesi M, Arnaboldi L, Fumagalli R, Paoletti R and Corsini A: Direct vascular effects of HMG-CoA reductase inhibitors. Atherosclerosis 137, Suppl S101 - S109 (1998)

12 Corsini A, Arnaboldi L, Raiteri M, Quarato P, Faggiotto A, Paoletti R and Fumagalli R: Effect of the new HMG-CoA reductase inhibitor cerivastatin (BAY W 6228) on migration, proliferation and cholesterol synthesis in arterial myocytes. Pharmacol Res 33, 55-61 (1996)

13 Kim SY, Guijarro C, O'Donnell MP, Kasiske BL, Kim Y and Keane WF: Human mesangial cell production of monocyte chemoattractant protein-1: modulation by lovastatin. Kidney Int 48, 363 - 371 (1995)

14 Weber C, Erl W, Weber KS and Weber PC: Effects of oxidized low density lipoprotein, lipid mediators and statins on vascular cell interactions. Clin Chem Lab Med 37, 243 - 251 (1999)

15 Hernandez-Perera O, Perez-Sala D, Navarro-Antolin J, SanchezPascuala R, Hernandez G, Diaz C and Lamas S: Effects of the 3-hydroxy-3-methylglutaryl-CoA reductase inhibitors, atorvastatin and simvastatin, on the expression of endothelin-1 and endothelial nitric oxide synthase in vascular endothelial cells. J Clin Invest 101, 2711 - 2719 (1998)

16 Vincent L, Chen W, Hong L, Mirshahi F, Mishal Z, MirshahiKhorassani T, Vannier JP, Soria J and Soria C: Inhibition of endothelial cell migration by cerivastatin, an HMG-CoA reductase inhibitor: contribution to its anti-angiogenic effect. FEBS Lett 495, 159 - 166 (2001)

17 Guijarro C, Kim Y, Schoonover CM, Massy ZA, O'Donnell MP, Kasiske BL, Keane WF and Kashtan CE: Lovastatin inhibits lipopolysaccharide-induced NF-kappaB activation in human mesangial cells. Nephrol Dial Transplant 11, 990 - 996 (1996)

18 Park JK, Muller DN, Mervaala EM, Dechend R, Fiebeler A, Schmidt F, Bieringer M, Schafer O, Lindschau C, Schneider W, Ganten D, Luft FC and Haller H: Cerivastatin prevents angiotensin II-induced renal injury independent of blood pres. Kidney Int 58, 1420 - 1430 (2000)

19 Bourcier T and Libby P: HMG CoA reductase inhibitors reduce plasminogen activator inhibitor-1 expression by human vascular smooth muscle and endothelial cells. Arterioscler Thromb Vasc Biol 20, 556 - 562 (2000)

20 Essig M, Nguyen G, Prie D, Escoubet B, Sraer JD and Friedlander G: 3-Hydroxy-3-methylglutaryl coenzyme A reductase inhibitors increase fibrinolytic activity in rat aortic endothelial cells. Role of geranylgeranylation and Rho proteins. Circ Res 83, $683-690$ (1998)

21 Edgell CJ, McDonald CC and Graham JB: Permanent cell line expressing human factor VIII-related antigen established by hybridization. Proc Natl Acad Sci USA 80, 3734 - 3737 (1983)

22 Rieber AJ, Marr HS, Comer MB and Edgell CJ: Extent of differentiated gene expression in the human endothelium-derived EA.hy926 cell line. Thromb Haemost 69, 476 - 480 (1993)

23 Swiatkowska M, Cierniewska-Cieslak A, Pawlowska Z and Cierniewski CS: Dual regulatory effects of nitric oxide on plasminogen activator inhibitor type 1 expression in endothelial cells. Eur J Biochem 267, 1001 - 1007 (2000)

24 Chomczynski P and Sacchi N: Single-step method of RNA isolation by acid guanidinium thiocyanate-phenol-chloroform extraction. Anal Biochem 162, 156 - 159 (1987)

25 De Muth JE: Basic Statistics and Pharmaceutical Statistical Applications, Marcel Dekker Inc., New York Basel (1999)

26 Thyberg J, Hedin U, Sjolund M, Palmberg L and Bottger BA: Regulation of differentiated properties and proliferation of 
arterial smooth muscle cells. Arteriosclerosis 10, 966-990 (1990)

27 Fuster V, Badimon L, Badimon JJ and Chesebro JH: The pathogenesis of coronary artery disease and the acute coronary syndromes (2). N Engl J Med 326, 310 - 318 (1992)

28 Sacks FM, Pfeffer MA, Moye LA, Rouleau JL, Rutherford JD, Cole TG, Brown L, Warnica JW, Arnold JM, Wun CC, Davis $\mathrm{BR}$ and Braunwald E: The effect of pravastatin on coronary events after myocardial infarction in patients with average cholesterol levels. Cholesterol and Recurrent Events Trial Investigators. N Engl J Med 335, 1001 - 1009 (1996)

29 Silva JM: Statins, high-density lipoprotein, and the low-density lipoprotein/high- density lipoprotein ratio (1). Am J Cardiol 86, 593 - 594 (2000)

30 Essig M, Vrtovsnik F, Nguyen G, Sraer JD and Friedlander G: Lovastatin modulates in vivo and in vitro the plasminogen activator/plasmin system of rat proximal tubular cells: role of geranylgeranylation and Rho proteins. J Am Soc Nephrol 9, $1377-1388$ (1998)

31 Wiesbauer F, Kaun C, Zorn G, Maurer G, Huber K and Wojta J: HMG CoA reductase inhibitors affect the fibrinolytic system of human vascular cells in vitro: a comparative study using different statins. Br J Pharmacol 135, 284 - 292 (2002)

32 Horne BD, Muhlestein JB, Carlquist JF, Bair TL, Madsen TE, Hart NI and Anderson JL: Statin therapy, lipid levels, C-reactive protein and the survival of patients with angiographically severe coronary artery disease. J Am Coll Cardiol 36, 1774-1780 (2000)

33 Rauch U, Osende JI, Chesebro JH, Fuster V, Vorchheimer DA, Harris K, Harris P, Sandler DA, Fallon JT, Jayaraman S and Badimon JJ: Statins and cardiovascular diseases: the multiple effects of lipid- lowering therapy by statins. Atherosclerosis 153, $181-189(2000)$
34 LaRosa JC: Poor compliance: the hidden risk factor. Curr Atheroscler Rep 2, 1 - 4 (2000)

35 Negre Aminou P, van Vliet AK, van Erck M, van Thiel GC, van Leeuwen RE and Cohen LH: Inhibition of proliferation of human smooth muscle cells by various HMG-CoA reductase inhibitors; comparison with other human cell types. Biochim Biophys Acta 1345, 259 - 268 (1997)

36 Endres M, Laufs U, Huang Z, Nakamura T, Huang P, Moskowitz MA and Liao JK: Stroke protection by 3-hydroxy-3-methylglutaryl (HMG)-CoA reductase inhibitors mediated by endothelial nitric oxide synthase. Proc Natl Acad Sci USA 95, 8880 - 8885 (1998)

37 Laufs U and Liao JK: Post-transcriptional regulation of endothelial nitric oxide synthase mRNA stability by Rho GTPase. J Biol Chem 273, 24266 - 24271 (1998)

38 Laufs U, La Fata V, Plutzky J and Liao JK: Upregulation of endothelial nitric oxide synthase by HMG CoA reductase inhibitors. Circulation 97, $1129-1135$ (1998)

39 Park HJ and Galper JB: 3-Hydroxy-3-methylglutaryl CoA reductase inhibitors up-regulate transforming growth factor-beta signaling in cultured heart cells via inhibition of geranylgeranylation of RhoA GTPase. Proc Natl Acad Sci USA 96, 11525 11530 (1999)

40 Laufs U, Gertz K, Huang P, Nickenig G, Bohm M, Dirnagl U and Endres M: Atorvastatin upregulates type III nitric oxide synthase in thrombocytes, decreases platelet activation, and protects from cerebral ischemia in normocholesterolemic mice. Stroke 31, 2442 - 2449 (2000)

41 Laufs U, Endres M, Stagliano N, Amin-Hanjani S, Chui DS, Yang SX, Simoncini T, Yamada M, Rabkin E, Allen PG, Huang PL, Bohm M, Schoen FJ, Moskowitz MA and Liao JK: Neuroprotection mediated by changes in the endothelial actin cytoskeleton. J Clin Invest 106, 15 - 24 (2000) 